\title{
Chemoprotective Agent
}

National Cancer Institute

\section{Source}

National Cancer Institute. Chemoprotective Agent. NCI Thesaurus. Code C2459.

Chemicals which protect normal cells from the effects of chemotherapy. 